PROCEDIA

Studi Kasus dan Intervensi Psikologi ISSN:2302-1462; e-ISSN: 2722-7669

Volume 8(3) 127-134, September 2020

DOI: $10.22219 /$ procedia.v8i3.14305

\title{
Anger Management untuk mengontrol dorongan rasa marah pada pasien skizofrenia
}

Pertiwi Nurani, Universitas Muhammadiyah Malang, Malang, Indonesia

Korespondonesi:

Pertiwi Nurani, email: pertiwinurani20@gmail.com

\begin{abstract}
Riwayat artikel Naskah diterima:

$11 / 06 / 2020$

Revisi diterima:

$13 / 08 / 2020$

Naskah disetujui: $21 / 09 / 2020$
\end{abstract}

\begin{abstract}
Abstrak
Skizofrenia merupakan kelompok gangguan psikotik, dicirikan dengan kekacauan pada kognisi dan emosi yang memengaruhi aktivitas mendasar seperti emosi, pikiran, persepsi dan afeksi serta pemahaman akan diri. Studi kasus ini menggunakan subjek pasien skizofrenia. Berdasarkan hasil asesmen subjek didiagnosis mengalami gangguan skizofrenia dengan permasalahan ketidakmampuan mengontrol dorongan rasa marah. Intervensi yang diberikan berupa anger management untuk mengurangi dorongan rasa marah. Hasil intervensi menunjukkan, subjek belum mampu mengontrol dorongan rasa marah ketika rokok dan uang yang diminta tidak segera diberikan. Namun agresi verbal telah berkurang yang ditandai dengan berkurangnya frekuensi mengumpat dan mengeluh ketika tidak diberikan rokok ataupun uang dan mulai dapat berinteraksi dengan lingkungan.

Kata kunci: Skizofrenia, anger management, mengontrol rasa marah.
\end{abstract}

\section{Latar Belakang}

Skizofrenia merupakan kelompok gangguan psikotik, dicirikan dengan kekacauan pada kognisi dan emosi yang memengaruhi aktivitas mendasar seperti emosi, pikiran, persepsi dan afeksi serta pemahaman akan diri. Kerentanan terhadap kekacauan tersebut diakibatkan oleh adanya suara-suara yang menggumam namun tidak diketahui sumbernya dan meyakini keyakinan yang salah. Hal tersebut memengaruhi keberfungsian diri dan sosial (Arango, Kirkpatrick, \& Buchanan, R., 2000; Boeree, 2013; Picchioni \& Murray, 2007). Simtom ditunjukkan kurang lebih selama satu bulan sehingga gejala yang tampak adalah seperti kondisi fisik yang tidak terawat, kehilangan kontak dengan realitas, tidak mampu untuk membedakan orang-orang yang berada disekitarnya, dan tidak mengenal tempat serta waktu (APA, 2013; Castonguay \& Oltmanns, 2013; Tandon et al., 2013).

Gejala-gejala positif penderita skizofrenia ditunjukkan dengan adanya halusinasi yakni distorsi yang dilebih-lebihkan terhadap persepsi indra. Kemudian, adanya delusi atau kekeliruan 
terhadap keyakinan atau melebih-lebihkan pikiran sehingga terjadi kesalahan dalam menafsirkan pengalaman yang dialami. Adanya kekacauan dalam berpikir sehingga ketika berbicara pertanyaan yang diajukan dijawab tidak sesuai dengan konteksnya. Menunjukkan adanya perilaku yang kacau yakni kesulitan dalam merawat diri sendiri, tidak adanya rasa malu dan takut, tidak mengenal tempat dan waktu serta orang-orang disekitarnya. Terakhir, adanya perilaku katatonik yakni penurunan fungsi terhadap lingkungan sekitar, berbentuk kekakuan pada fungsi tubuh dan aneh, keterpakuan dan aktivitas motorik berlebihan dan tidak dapat dikendalikan (Boeree, 2013; APA, 2013; Nevid, Rathus, \& Greene, 2014).

Permasalahan yang dialami subjek pada fase pemulihan terkait ketidakmampuan dalam mengontrol dorongan rasa marah. Subjek merupakan pasien skizofrenia laki-laki dewasa yang baru selesai menjalani perawatan di rumah sakit jiwa. Subjek memiliki gejala skizofrenia sejak berusia 17 tahun dan telah mendapat perawatan di Puskesmas hingga RSJ. Kekambuhan subjek terjadi akibat kurangnya kemampuan dalam menyelesaikan permasalahan yang dihadapi dan enggan berkomunikasi serta meminta saran kepada keluarga atau orang lain.

Kondisi subjek semakin parah pada tahun 2016 saat bercerai dengan istrinya dan terpisah dari anak. Subjek yang tidak terima merasa kecewa dan marah, namun tidak dapat menolak dan menentang perceraian tersebut. Selama dua tahun subjek berada di rumah, tidak banyak aktivitas yang dapat dilakukan. Hal tersebut menyebabkan subjek cenderung keluyuran di luar rumah, merokok, mondar mandir di dalam dan di luar rumah. Subjek juga merusak barang-barang baik di rumah sendiri maupun milik tetangga. Selain itu, subjek sering memukul ibu tanpa sebab dan berteriak-teriak, mengumpat dan cenderung sering mengeluh dengan kondisi penyakit yang dialami. Hal ini menunjukkan kurangnya kemampuan dalam mengontrol dorongan rasa marah dan agresi diri untuk menghadapi penyakitnya dan fungsi di dalam lingkungan, sehingga intervensi anger management diperlukan untuk mengatasi hal tersebut.

Intervensi yang memiliki bukti kuat terhadap perubahan, pengurangan gejala pada pasien skizofrenia yakni terapi kognitif perilaku (Byrne, 2007; Corrigan \& Yudofsky, 1993; Glancy, Frcp, \& Saini, 2005). Salah satu teknik dari terapi kognitif perilaku yakni anger management. Pada beberapa penelitian sebelumnya disebutkan bahwa anger management sebagai salah satu teknik terapi yang dapat digunakan untuk mengurangi ekspresi kemarahan dan meningkatkan kemampuan pengendalian amarah (Chan, Lu, Tseng, \& Chou, 2003; Levey \& Howells, 1990). Selain itu, anger management juga cukup berpengaruh terhadap penurunan tingkat agresi verbal pada pasien skizofrenia (Wahyuningsih, 2016).

\section{Metode Asesmen}

Metode asesmen yang digunakan berupa wawancara, observasi, dan pemberian tes psikologi sebagai penunjang informasi terkait dengan penegakan diagnosis. Wawancara dilakukan terhadap subjek dan keluarga yang bertujuan untuk mendapatkan informasi secara mendalam dan rinci terkait dengan riwayat permasalahan dari subjek. Observasi dilakukan untuk pemeriksaan status mental meliputi penampilan fisik subjek, perilaku sehari-hari, afek, gangguan persepsi, orientasi dan kesadaran subjek.

Tes psikologi yang digunakan mencakup Woodworth's Questionnaire (WWQ) sebagai alat bantu untuk mengetahui kecenderungan kondisi patologis subjek. Tes kepribadian yaitu tes grafis (DAP, HTP dan Baum), TAT, SSCT, dan WAIS. Tes grafis bertujuan untuk mengetahui kepribadian subjek secara lebih mendalam. Tes TAT digunakan untuk mengetahui defence mechanism, kebutuhan, afeksi, dan tekanan yang tidak dapat diungkapkan subjek secara langsung. Tes SSCT digunakan untuk mengelompokkan permasalahan yang dialami oleh subjek, sedangkan WAIS untuk mengetahui kapasitas intelektual subjek dan juga gejala klinis pada subjek. Terakhir, Clinical Anger Scale (CAS) digunakan untuk melihat perubahan sebelum dan setelah intervensi dilakukan. 


\section{Presentasi Kasus}

Subjek merupakan seorang laki-laki, berusia 34 tahun, anak kedua dari lima bersaudara dan berstatus duda. Subjek adalah pasien skizofrenia dengan onset gangguan sejak remaja yakni usia 17 tahun. Riwayat permasalahan subjek dimulai saat di bangku Sekolah Menengah Pertama (SMP). Selama duduk di bangku SMP, subjek sering dipanggil oleh guru Bimbingan \& Konseling (BK) karena sering bolos sekolah dan ikut tawuran. Ketika mengikuti tawuran subjek memiliki perasaan senang dan bangga karena bisa dikenal oleh teman-temannya. Setelah lulus SMP, subjek meminta kepada orang tua untuk melanjutkan sekolah ke jenjang SMA, namun keinginannya tidak terpenuhi. Hal ini menyebabkan subjek memutuskan untuk mencari pekerjaan. Pada tahun 2004, subjek diterima bekerja pertama kali di perusahaan jasa kredit sebagai satpam.

Suatu hari ketika subjek bekerja, salah seorang temannya mengatakan bahwa subjek selama bekerja malas dan hanya bisa mendekati perempuan. Mendengar perkataan tersebut, subjek marah dan memukul temannya di dalam gudang. Kejadian ini disaksikan oleh dua orang rekan kerjanya. Akibat kejadian ini, subjek dikeluarkan dari pekerjaannya. Setelah kejadian ini, subjek lebih banyak diam, sering menyendiri dan berjalan mondar mandir sambil merokok. Masalah ini menjadi pencetus pertama kali subjek memunculkan gejala dari gangguan skizofrenia.

Melihat kondisi dan perilaku aneh yang ditampakkan subjek, maka keluarga memutuskan untuk membawa subjek ke Puskesmas. Setelah diperiksa dan diberikan obat, subjek kembali melakukan aktivitas dan berinteraksi dengan lingkungannya. Kemudian, subjek kembali bekerja sebagai satpam di salah satu perusahaan. Selama bekerja, subjek bergaul dengan teman kerja yang sering bermain judi dan minum-minuman keras, sehingga berdampak pada perilaku subjek. Subjek cenderung sering marah dan tertutup terkait pekerjaannya.

Selanjutnya, pada tahun 2011 subjek menikah dan tinggal bersama dengan istri di dekat rumah orang tua istri. Suatu hari, subjek datang berkunjung ke rumah orang tua dan disuguhkan makanan sederhana yakni nasi, tempe, dan tahu. Subjek tidak menolak ketika diberi makanan tersebut. Namun ketika makan, subjek memuntahkan makanan sehingga membuat ibunya mempertanyakan terkait dengan rasa makanan. Kemudian, subjek mengatakan bahwa rasa makanannya berbeda dengan yang selalu dimasak oleh istrinya. Selain itu, subjek juga mempermasalahkan masalah lauk yang dihidangkan sehingga membuat ibunya tersinggung, namun berusaha untuk memakluminya.

Setelah lima tahun pernikahan, pada tahun 2016 sang istri meminta untuk bercerai karena merasa takut dan khawatir terhadap kondisi kejiwaan subjek. Setelah berpisah, istri subjek membawa serta anaknya dan kemudian menikah lagi dengan bos di tempatnya bekerja. Hal ini menyebabkan kondisi subjek semakin buruk yang ditandai dengan mengurung diri. Kemudian, ketika berada di luar kamar modar-mandir tanpa arah, berbicara sendiri, mengaku melihat bayangan hitam, membawa senjata tajam dan mengejar adik karena dianggap penjahat, menyayat-nyayat batang pohon pisang karena dianggap pencuri, memukul ibu tanpa sebab, tidak merawat diri, dan mulai tidak mengenali lingkungan sekitarnya.

Selama di rumah, subjek menujukkan gejala-gejala lain seperti merusak dan membuang barang yang ada di dalam rumah. Suatu hari, subjek pergi menggunakan motor dan sengaja menabrak orang yang sedang berjalan sehingga keluarga memutuskan untuk menyita motornya. Hal tersebut menyebabkan subjek mulai berjalan-jalan di luar rumah hanya menggunakan celana pendek dan mengetuk-ngetuk pintu rumah tetangga.

Selain itu, subjek pergi ke rumah tetangga mengambil burung dan mangga milik tetangga. Suatu hari subjek membawa pisau ditangannya dan mengejar adiknya berkeliling rumah. Hal ini dilakukannya karena melihat bayangan hitam berada disekitar adiknya. Di luar rumah sering menyetop mobil secara tiba-tiba, meminta-minta uang, marah-marah dan memukul ibu, BAB dan BAK disembarang tempat. Hal ini membuat keluarga semakin sedih dan tidak enak hati. 
Kondisi subjek yang semakin parah juga membuat lingkungan sekitarnya mulai mengucilkan keluarga subjek. Akhirnya, keluarga memutuskan untuk membawa subjek ke Rumah Sakit Jiwa (RSJ) untuk berobat.

Ketika berada di RSJ dan bertemu dengan terapis, subjek sebanyak tiga kali menunjukkan ekspresi kemarahan karena permintaannya tidak dipenuhi secara langsung dan juga menggunakan kalimat mengancam untuk mendapatkan yang diinginkan. Subjek juga ingin memukul salah satu teman satu bangsal karena kesal. Tidak hanya itu, subjek juga menunjukkan ekspresi kemarahan ketika orang-orang di lingkungan sekitarnya membuat subjek merasa tidak nyaman. Salah satunya, ketika melihat pertengkaran yang terjadi pada ruang rehabilitasi, subjek cukup merasa marah dan kesal atas keributan itu.

Berdasarkan uraian perjalanan gangguan, dapat diketahui bahwa ada pemicu terbentuknya dorongan rasa marah pada subjek. Hal ini dapat digambarkan melalui konsep teori kontrol diri Skinner. Skinner mengemukakan bahwa sebenarnya individu memiliki kemampuan untuk mengendalikan perilakunya sendiri. Individu "memilih" untuk melakukan berbagai tindakan alternatif dengan cara "berpikir" bahwa mereka harus melakukan "kontrol diri" untuk terhindar dari rasa terisolasi lingkungan dan menjaga kesehatan serta posisinya di masyarakat (Skinner, 1965).

Subjek memiliki ketidakmampuan dalam mengontrol diri terhadap dorongan rasa marah. Dorongan tersebut hadir saat harapan dan keinginannya tidak terpenuhi secara langsung. Seperti, ketika subjek meminta untuk diberikan uang, namun tidak segera diberikan maka respon yang ditunjukkan yakni hadirnya dorongan rasa marah dan ekspresi kemarahan terhadap orang-orang yang berada disekitarnya.

\section{Diagnosis dan Prognosis}

Hasil diagnosis subjek telah memenuhi kriteria diagnostik DSM-V untuk gangguan skizofrenia (295.90). Permasalahan yang dimunculkan adalah ketidakmampuan dalam mengontrol dorongan rasa marah. Prognosis pada subjek mengarah pada suatu keadaan yang baik. Hal tersebut berkaitan dengan motivasi yang baik dari diri subjek serta dukungan dari seluruh anggota keluargan dan orang terdekat subjek. Selain itu, motivasi yang kuat subjek untuk sembuh dan segera bekerja kembali seperti sebelum menderita gangguan jiwa.

\section{Intervensi}

Intervensi menggunakan teknik anger management yang berguna sebagai sarana untuk memaksimalkan kebahagiaan dan kesejahteraan diri subjek. Ketika subjek dapat menerima kondisi saat ini dan berusaha untuk menahan amarah, maka subjek dapat mempersiapkan diri untuk mengatasi rasa sakit, frustrasi, kemarahan, dan menjalani hidup lebih mudah dan efektif. Anger management bertujuan untuk memahamkan tentang kondisi yang dapat diubah dan tidak dapat diubah. Selain itu, subjek diajarkan untuk merefleksikan diri, kehidupan di rumah, dan masa depan yang diharapkan oleh subjek (Puff \& Seghers, 2014). Subjek memiliki dorongan rasa marah yang cukup tinggi. Hal ini berdasarkan pada kuesioner Clinical Anger Scale (CAS) (Snell et al., 1991) yang diberikan kepada subjek sebelum melaksanakan intervensi. Hasil menunjukkan nilai 32 yang berarti bahwa tingkat marah subjek berada pada taraf severe clinical anger yang sebaiknya segera untuk ditangani.

Terapi anger management terbagi ke dalam 8 sesi, termasuk psikoedukasi kepada keluarga agar mempersiapkan kepulangan subjek dan menyambutnya dengan suka cita (Lök, Bademli, \& Canbaz, 2018; Puff \& Seghers, 2014; Nay, 2007). Anger management dilakukan dalam rentang waktu 60-90 menit, meliputi:

Sesi I: Building rapport dan Informed consent. Pada sesi ini, terapis membangun rapport dan memberikan informed consent kepada wali dan subjek. Membangun rapport berlangsung 
selama satu minggu. Kemudian, subjek diberikan Clinical Anger Scale untuk mengukur kondisi awal subjek. Home visit dilakukan untuk menggali informasi dari keluarga subjek. Terapis juga menyampaikan kepada keluarga terkait dengan tindakan intervensi yang akan diberikan kepada subjek termasuk dengan edukasi terkait gangguan, permasalahan subjek serta cara penanganan ketika subjek dipulangkan. Setelah home visit dan edukasi, anggota keluarga mendukung intervensi yang diberikan dan belajar untuk mencegah kekambuhan subjek. Proses membangun rapport dengan keluarga dilakukan sebanyak dua kali. Hasil membangun rapport ini masih terus berlangsung hingga subjek dipulangkan.

Sesi II: Relaksasi. Pada sesi ini, subjek mulai dilatih untuk menenangkan dan mengontrol diri melalui latihan pernapasan dan peregangan otot badan. Pada awalnya, subjek menolak untuk melakukan latihan relaksasi karena subjek beranggapan bahwa yang diajarkan membutuhkan waktu yang lama dan tidak segera mengatasi dorongan rasa marah. Namun, setelah diajarkan 3 sampai 5 kali latihan relaksasi selama 2 hari, subjek merasakan bahwa yang diajarkan lebih membantu untuk menenangkan diri sehingga tidak langsung marah kepada orang lain.

Sesi III: Identifikasi penyebab dan kondisi yang memunculkan kemarahan. Pada sesi ini, subjek mencoba untuk mengidentifikasi hal-hal yang dapat diterima dan tidak dapat diterima sehingga memunculkan dorongan rasa marah. Selanjutnya, subjek diberikan pertanyaan tentang hal-hal yang menyababkannya marah. Subjek bisa menjawab setelah diberikan pertanyaan 3 hingga 4 kali. Hasil dari identifikasi tersebut adalah subjek memunculkan rasa marah ketika tidak segera diberi rokok, tidak diberi uang, diberi batasan untuk makan, dan dibangunkan ketika sedang tidur. Kondisi-kondisi tersebut yang paling dianggap mengganggu subjek.

Sesi IV: Identifikasi perilaku yang dimunculkan ketika dorongan rasa marah hadir. Pada sesi ini, subjek mengidentifikasi perilaku yang dimunculkan ketika dorongan rasa marah mulai hadir. Subjek menyampaikan bahwa ketika marah ia akan melempar barang-barang atau memarahi ibunya atau secara tidak sengaja memukul ibu dan anggota keluarga lain. Hasil ini didapatkan setelah dua kali pertemuan dengan subjek.

Sesi V: Kontrol diri terhadap dorongan rasa marah.Pada sesi ini, subjek diajarkan untuk melakukan latihan relaksasi setiap pagi bersama dengan salah satu anggota keluarga (orang tua). Subjek juga diminta untuk melakukan olahraga ringan sebagai bentuk peluapan energi. Selain itu, diberikan aktivitas bermanfaat untuk membantu orang tua membersihkan rumah dan mencuci piring serta baju sendiri. Perilaku ini ditujukan agar subjek dapat teralihkan dengan aktivitas yang lebih bermanfaat dan tidak merasa kosong. Orang tua juga diminta untuk mengajak subjek melakukan kegiatan yang ringan seperti membantu di sawah untuk mengambil pakan sapi. Namun, hasil pada sesi ini masih belum konsisten. Kegiatan tersebut diberikan selama 2 minggu dengan bantuan observasi dari keluarga.

Sesi VI: Evaluasi. Pada sesi ini, subjek mampu untuk melakukan aktivitas harian setiap pagi dan sore tanpa diminta. Subjek juga dengan suka rela membantu ayah di sawah untuk mencari rumput pakan sapi. Selain itu, subjek ingin mulai bekerja namun karena keterbatasan fisik yang kaku dan masih sering tremor maka ia hanya dapat bekerja ketika diawasi oleh anggota keluarga. Hal ini menunjukkan bahwa proses intervensi dapat diterima oleh subjek dan keluarga. Setelah dirasa cukup, terapis lalu mengakhiri sesi dan memberikan kembali Clinical Anger Scale untuk mengukur kondisi akhir subjek setelah diberikan intervensi. Pada sesi ini, terapis menanyakan kepada subjek dan keluarga hal-hal yang telah didapatkan selama intervensi dilakukan.

Sesi VII: Terminasi. Pada sesi ini, keluarga melakukan upaya untuk membantu subjek agar tetap mengontrol dorongan rasa marah tanpa bantuan terapis. Hasil pada sesi ini, keluarga melakukan aktivitas dengan subjek tanpa harus memaksa terlebih dahulu. Subjek juga tidak lagi memaksa untuk selalu diberi rokok dan uang sesuai dengan kehendaknya. 
Sesi VIII: Follow up. Pada sesi ini, terapis menghubungi anggota keluarga dan subjek untuk menanyakan perubahan dan perkembangan pada subjek pasca intervensi diberikan. Setelah dua minggu pasca intervensi, dorongan rasa marah subjek cukup berkurang. Hal ini ditandai dengan subjek mampu untuk tidak memarahi orang-orang disekitar ketika dilarang atau tidak diberikan rokok ataupun uang.

\section{Hasil dan Pembahasan}

\section{Hasil}

Proses intervensi yang diberikan kepada subjek berjalan dengan lancar, termasuk psikoedukasi yang diberikan kepada keluarga dan pengurus RT. Keluarga masih belum mampu mengontrol perilaku subjek seperti meminta rokok namun tetap berupaya memberikan pengertian ketika tidak dapat memenuhi permintaannya. Selain itu, keluarga juga aktif memberikan kegiatan harian kepada subjek berupa bersih diri dan mengurus diri sendiri termasuk mencuci piring dan mencuci baju yang telah digunakan. Pengurus RT juga diberikan pemahaman tentang kondisi subjek saat ini yang berbeda dibandingkan sebelum dibawa ke RSJ. Gambar 1 merupakan bagan yang menunjukkan hasil intervensi sebelum dan sesudah intervensi.

Berdasarkan hasil tes di awal intervensi dengan menggunakan CAS, subjek mendapatkan skor sebesar 32. Skor tersebut berada pada kategori severe clinical anger. Artinya, subjek memiliki masalah terkait dengan rasa marah, baik dari dorongan rasa marah hingga perilaku yang diakibatkan oleh rasa marah dan rasa bermusuhan dengan orang lain. Namun, setelah intervensi diberikan terlihat penurunan yang cukup signifikan dengan skor sebesar 9. Skor tersebut berada pada kategori minimal clinical anger. Hal ini menunjukkan bahwa terdapat penurunan dorongan rasa marah subjek setelah diajarkan perilaku baru yang lebih efektif dan melibatkan anggota keluarga dalam penanganannya.

\section{Pembahasan}

Tindakan agresi karena hadirnya dorongan rasa marah pada pasien skizofrenia memiliki dampak trauma bagi anggota keluarga. Hal ini sangat dirasakan oleh ibu subjek sebagai korban dari tindakan agresi (Loughland et al., 2009). Pemilihan intervensi anger management juga didasarkan pada kebutuhan keluarga yang menganggap bahwa perilaku tersebut yang paling memiliki dampak. Pemberian anger management dalan intervensi ini juga melibatkan seluruh anggota yakni ayah, ibu, kakak, dan adik sebagai caregiver setelah subjek dipulangkan dari RSJ.

Pemahaman dan pengontrolan harian terhadap kondisi gangguan jiwa subjek telah disesuaikan dengan ketertarikan dan kemampuan subjek. Namun, tidak mudah untuk pasien skizofrenia melakukan penerapan dan pengontrolan terhadap diri sendiri tanpa arahan dan

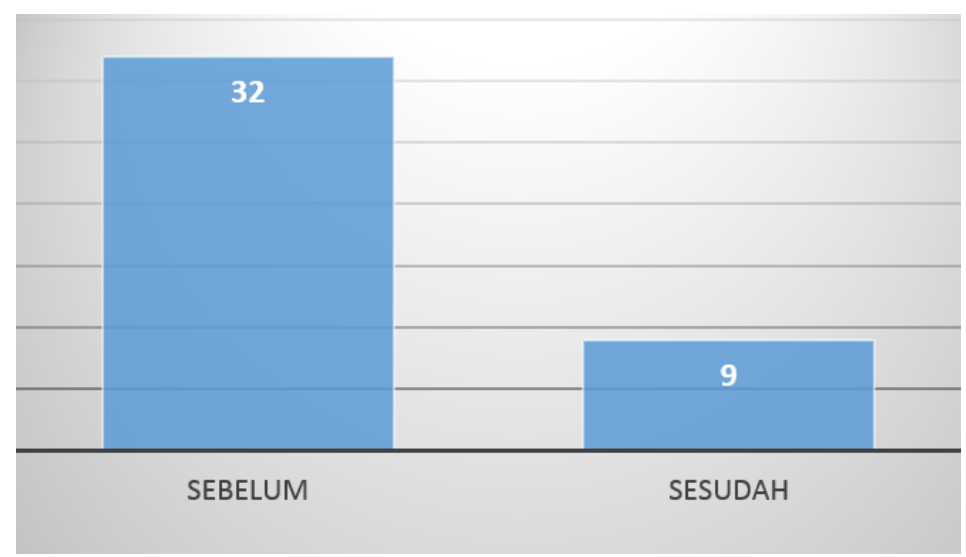

Gambar 1. Hasil sebelum dan sesudah intervensi. 
bimbingan dari orang lain. Oleh karena itu, peran keluarga untuk melakukan arahan dan pendampingan kepada subjek menjadi salah satu faktor penting dalam intervensi ini. Keluarga memiliki peran penting dalam peningkatan hasil intervensi setelah diberikan informasi tentang pentingnya konsumsi obat secara teratur dan kekompakan keluarga untuk mendukung pemulihannya.

Hasil yang baik dapat dicapai dengan adanya manajemen dan perawatan subjek dengan melibatkan para profesional, keluarga, dan subjek sendiri. Hal ini berguna untuk mengurangi penderitaan antar anggota keluarga dengan mendukung dan memberikan informasi terkait dengan pemulihan subjek. Selain itu, subjek juga mampu menumbuhkan rasa tanggung jawab, dan berupaya menjadi orang yang baik serta saling bekerja sama untuk pemulihan kondisinya (Falloon et al., 2010; Hernandez-yánez et al., 2015; Mannerheim, Muhli, \& Siouta, 2016; Mcfarlane et al., 2003).

Selain dari dukungan keluarga, anger management memberikan perubahan positif terhadap pikiran dan perilaku karena didalam terapi ini terdapat penentuan target perilaku terhadap pengontrolan dorongan rasa marah. Konsekuensi yang tampak yakni perubahan emosional dan perilaku berasal dari kondisi pengaktifan yang diinterpretasi oleh individu (Lam \& Gale, 2000). Hal ini juga berlaku pada subjek dengan memberikan pemahaman terhadap kondisi-kondisi yang tidak terduga maka subjek dapat mengontrol dorongan rasa marah sebagai efek dari kemampuan dalam memahami kondisi tersebut.

\section{Simpulan}

Anger management terbukti efektif dalam membantu pasien skizofrenia dalam mengontrol dorongan rasa marah di lingkungan, sehingga menurunkan agresi verbalnya. Peran keluarga dalam memberikan arahan dan pendampingan menjadi hal penting dalam keberhasilan intervensi. Selain itu, target intervensi secara realistis menjadi prinsip penting dalam mengubah pola pikir dan mengontrol perasaan marah. Hal ini membantu tercapainya target intervensi. Intervensi diberikan dengan tidak mengesampingkan fungsi obat serta pemeriksaan medis, sehingga tetap dilakukan pemeriksaan secara rutin.

\section{Referensi}

American Psychiatric Association. (2013). Diagnostic and statistial manual (5th ed.) Washington, DC: American Psychiatric Publishing.

Arango, C., Kirkpatrick, B., \& Buchanan, R., W. (2000). Neurological signs and the heterogeneity of schizophrenia. American Journal of Psychiatry, 157(4), 560-565.

Boeere, C. G. (2013). General psychology: psikologi kepribadian, persepsi, kognisi, emosi, \& perilaku. Jogjakarta: Prismasophie.

Byrne, P. (2007). Managing the acute psychotic episode. British Medical Journal, 334, 686-692. Castonguay, L. G., \& Oltmanns, T. F. (2013). Psychopathology: from science to clinical practice. New York: The Guildford Press.

Chan, H., Lu, R., Tseng, C., \& Chou, K. (2003). Effectiveness of the anger-control program in reducing anger expression in patients with schizophrenia. Archives of Psychiatric Nursing, 17(2), 88-95.

Corrigan, W., \& Yudofsky, C. (1993). Pharmacological and behavioral treatments for aggressive psychiatric inpatients. Hospital and Community Psychiatry, 44(2), 125- 133.

Falloon et al. (2010). Family management in the prevention of exacerbations of schizophrenia: a controlled study. Journal Od Medicine, 306(24), 1437-1440.

Glancy, G., Frcp, C., \& Saini, M. A. (2005). An evidenced-based review of psychological treatments of anger and aggression. Brief Treatment and Crisis Intervention, 5(2), 229-248.

Hernandez-yánez, H. D., et al. (2015). Family support and adherence to treatment in patients diagnosed with schizophrenia in tabasco, mexico: a case- series study. Journal of Psychiatry, 18(5), 1-4.

Lam, D., \& Gale, J. (2000). Cognitive behaviour therapy: teaching a client the ABC model - the first step towards the process of change. Journal of Advanced Nursing, 31(2), 444-451.

Levey, S., \& Howells, K. (1990). Anger and its management. The Journal of Forensic Psychiatry, 1(3), 305-327. 
Lök, N., Bademli, K., \& Canbaz, M. (2018). Archives of psychiatric nursing the effects of anger management education on adolescents manner of displaying anger and self-esteem: a randomized controlled trial. Archives of Psychiatric Nursing, 32(1), 75-81.

Loughland, C. M., et al. (2009). Aggression and trauma experiences among carer-relatives of people with psychosis. Social Psychiatry and Psychiatric Epidemiology, 44(12), 1031-1040.

Mannerheim, A. B., Muhli, U. H., \& Siouta, E. (2016). Parents experiences of caring responsibility for their adult child with schizophrenia. Schizophrenia Research and Treatment, 1-12.

Mcfarlane, W. R., Dixon, L., Lukens, E., \& Lucksted, A. (2003). Family psychoeducation and schizophrenia: A review of the literature. Journal of Marital and Family Therapy, 29(2), 223-245.

Nevid, J. S, Rathus, S. A., \& Green, B. (2014). Psikologi abnormal. Jakarta: Erlangga.

Picchioni, M. M., \& Murray, R. M. (2007). Schizophrenia. British Medical Journal, 335, 91-95.

Puff, R., \& Seghers, J. (2014). The everything guide to anger management: Proven techniques to understand and control anger. Massachusetts: Adam Media.

Skinner, B. F. (1965). Science and human behavior. Cambridge: The B. F Skinner Foundation.

Snell et al. (1991). The clinical anger scale: preliminary reliability and validity. Journal of Clinical Psychology, $51(2), 215-226$.

Tandon, R., et al. (2013). Definition and description of schizophrenia in the DSM-5. Schizophrenia Research, 150, 3-10.

Wahyuningsih, Y. P. (2016). Pelatihan keterampilan manajemen marah untuk agresi verbal orang dewasa dengan gangguan psikotik singkat. Jurnal Intervensi Psikologi, 8(1), 67-88. 